\title{
THE ANALYSIS OF CRACKS IN BEAMS OF QUAY NO. 80A AT KLAIPEDA PASSENGER AND CARGO TERMINAL
}

Raimondas SADZEVICIUS, Institute of Hydraulic Engineering, Aleksandras Stulginskis University, Universiteto str. 10, LT-53361 Akademija, Kaunas distr., Lithuania, raimondas.sadzevicius@asu.It (corresponding author)

Vincas GURSKIS, Institute of Hydraulic Engineering, Aleksandras Stulginskis University. Universiteto str. 10, LT-53361 Akademija, Kaunas distr., Lithuania, vincas.gurskis@asu.lt

Tatjana SANKAUSKIENE், Institute of Hydraulic Engineering, Aleksandras Stulginskis University, Universiteto str. 10, LT-53361 Akademija, Kaunas distr. Lithuania, tatjana.sankauskiene@asu.lt

Vitas DAMULEVIČIUS, Institute of Hydraulic Engineering, Aleksandras Stulginskis University, Universiteto str. 10, LT-53361 Akademija, Kaunas distr. Lithuania, vitas.damulevicius@asu.lt

Virginija GURSKIENÉ, Institute of Land Management and Geomatics, Aleksandras Stulginskis University, Universiteto str. 10, LT53361 Akademija, Kaunas distr. Lithuania, virginija.gurskiene@asu.lt

The cracks can be technological, appear during the usage time of construction, they can also be regular, and appear under the design load or they can also be unexpected and appear due to accidental impacts. Our research has shown that the cracks have appeared in reinforced concrete beams of the superstructure in quays No. 80 and 81 after the construction of Klaipeda Passenger and cargo terminal are caused by shrinkage strain, when the reinforced concrete beams has hardened. Normal hardening concrete shrinkage deformation is inevitable, but it depends on a number of factors, in particular, that in the present structures occurred because:

- W/C ratio of concrete mixture exceeds the allowable values;

- coarseness of selected aggregates $(\mathrm{D}=16 \mathrm{~mm})$ are too small for the construction of a massive wall;

- concrete stratification and possible lack of care for hardening concrete (ambient temperature, etc.), this segregation could be affected by to big spread of concrete mixture (class of slump S3).

The crack width at reinforced concrete beams in the superstructure of quay No. 80 varies from 0.05 to $0.5 \mathrm{~mm}$. This are a non-structural cracks, so they do not reduce significantly the mechanical strength and stability of the structure. Also, research has shown that the relationship between the crack width and the distance between the cracks is weak. Proposals for elimination of potential causes of cracking are presented according to the results.

Keywords: quays, concrete shrinkage, cracks.

\section{INTRODUCTION}

The number of tourists who come to Klaipeda on a ferry or a cruise ship, is growing every year, therefore Klaipeda port is preparing intensively to offer them an appropriate reception of high quality. For that purpose, the construction of the new Klaipeda passenger and cargo terminal was started in 2009. This terminal brightened the architecture of the city with a building of a particular construction and the port can now assure a quick and easy passengers service of the highest quality and the quality of its facilities. While building Klaipeda passenger and cargo terminal, cracks have appeared in reinforced concrete beams of the superstructure in quays No. 80 and 81 . In order to evaluate the possible risks of these cracks, an examination was carried out (Expertise of cracks..., 2012).

The most important criteria for the evaluation element's cracking is the risk to the construction caused by cracking. In this perspective, the following groups of cracks can be distinguished (Chen et al., 2005):

1. Harmless cracks which only erode quality of surface;

2. Harmful cracks, which considerably weaken the cross-section of construction;

3. Partly harmful cracks, which worsen the usage of element, reduce the liability and the durability of structure; however, they do not cause any direct danger. In this case, additional factors must be present for the structure to disintegrate.

It is known that cracks can be technological, appear during the usage time of construction, they can also be regular, such cracks appear under the design load or they can also be unexpected and appear due to accidental impacts. The main classification of cracks according to causes of appearance and features is presented in scientific literature (Jokubaitis, Sauciuvenas, 2012). On the basis of this classification, technological cracks usually belong to the 1st and 2nd categories of

Copyright (C) 2017 The Authors. Published by Aleksandras Stulginskis University. This is an open-access article distributed under the terms of the Creative Commons Attribution License (CC-BY 4.0), which permits unrestricted use, distribution, and reproduction in any medium, provided the original author and source are credited. 
damages which are considered to be harmless. According to the serviceability limit state, regular normal cracks of limited width are designed; they appear due to acting internal forces (Jokubaitis, Sauciuvenas, 2012) and they do not reduce the load-bearing of structures and have almost no impact on structures durability i.e. these cracks belong to the 1st category of defects. The width of cracks is calculated using condition according to which the width of cracks in a structure caused by various impacts and their combinations cannot surpass the limit value indicated in STR 2.05.05:2005 table 24). These calculations depend on the requirements for the structure, its usage conditions and the aggressiveness of environment.

When the width of these cracks caused by an overload in the level of tension reinforcement surpasses the limits indicated in the norms of design (STR 2.05.05:2005 table $24 w_{\mathrm{lim} 1}=0.20 \mathrm{~mm}$ ), they are already considered as damages.

The recommendations for quays' design (Recommendations ..., 2012) indicate that cracks of the width of a hair are not harmful to the structure until their width does not surpass $0.25 \mathrm{~mm}$. If the cracks do not belong to the category of "self-healing cracks", it is indispensable to seal them in order to avoid the reinforcement corrosion.

Volume changing cracking is a widespread problem in base restrained concrete walls (Kheder, G. F, 1997). The crackings' width dependencies on wall height and horizontal reinforcement (Rawi, Kheder, 1990), as well as on distance to the wall deformation junctures are constructed in scientific literature. Nevertheless, the crackings' width dependencies on the distance between cracks and the compressive strength of concrete of a structure is not determined in the analyzed literature, which shows the relevance and the novelty of this paper.

\section{AIM OF RESEARCH}

- To investigate the riskiness of cracks which have appeared in reinforced concrete beams of the superstructure in quays No. 80 and 81 of the Klaipeda Passenger and cargo terminal after the concrete structure works.

- To determine the reasons the appearance of cracks.

- To measure the width of cracks' openings and to check if they do not surpass the allowable limit values, also to measure the distance between cracks.

- To construct the dependencies of concrete strength on the distance between cracks and cracks' width.

\section{OBJECT OF RESEARCH}

The investigated structures is in the territory of Klaipeda National Port, on the East bank of the river Dane, in the region of the Curonian Lagoon. The reconstruction of quays No. 80 and 81 and the structure of the new pier No.80A, 81A are being performed between the quays No. 79 and No. 82. The scheme of the investigated structure is presented in figure 1 .

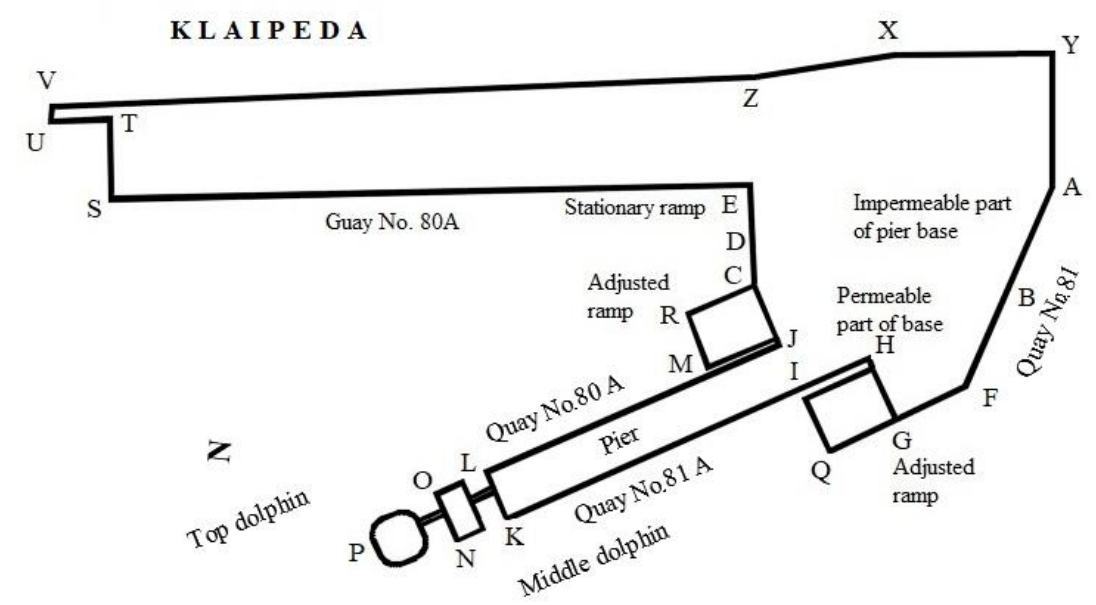

Figure 1. Scheme of quay No. 80, 80A and $81 \mathrm{~A}$ at Klaipeda passenger and cargo terminal

According to the Technical Construction Regulations "STR 2.02.06:2004 Hydraulic structures. The basic provisions" and "STR 1.01.03:2017 Classification of structures" the quays of seaports where the depth of water is more than $7 \mathrm{~m}$. belong to the category of particular structures. Consequently, the analyzed quays No. 80, 81, 80A and 81A are considered as particular structures. In this paper the authors present only the examination of cracks in the concrete of the quay No. 80A.

\section{METHODS OF RESEARCH}

The following methods were applied for the examination of concrete and reinforced concrete structures of the quay No. $80 \mathrm{~A}$ and the evaluation of their state:

- Visual examination: structures observation on site and the photo fixation of damaged elements.

- Non-destructive method for the determination of strength of concrete.

During the visual examination the preliminary structures observation and the simplest measurements of cracks were performed using such simple instruments as crack width ruler, caliper and scale ruler. During the examination of 
cracks in concrete beams of the superstructure in quay No. 80A, the distance between cracks were determined, the width of cracks was measured and the depth of the widest cracks was determined.

The determination of distance between cracks. The concrete beams of the superstructure in quay No. 80A are cracked, the distance between cracks was measured using measuring tape.

The evaluation of cracks width. The width of cracks of concrete beams of the superstructure in quay No. 80A was determined using crack width ruler (Fig. 2).

The non-destructive testing of compressive strength were performed in accordance with the European Standard EN 12504-2:2012 "Testing concrete in structures. Part 2. Non-destructive testing. Determination of rebound number" using the calibrated rebound device - the rebound hammer of concrete, Schmidt's hammer, which was calibrated using the standard anvil before and after every examination.

In accordance with European Standard EN 13791:2007 “Assessment of in-situ compressive strength in structures and precast concrete components" and European Standard EN 206:2017 "Concrete - Specification, performance, production and conformity" based on the concrete compressive strength, determined using non-destructive method, the characteristic strength of concrete was determined guaranteed with the probability of $95 \%$ and the class of compressive strength of concrete was selected.
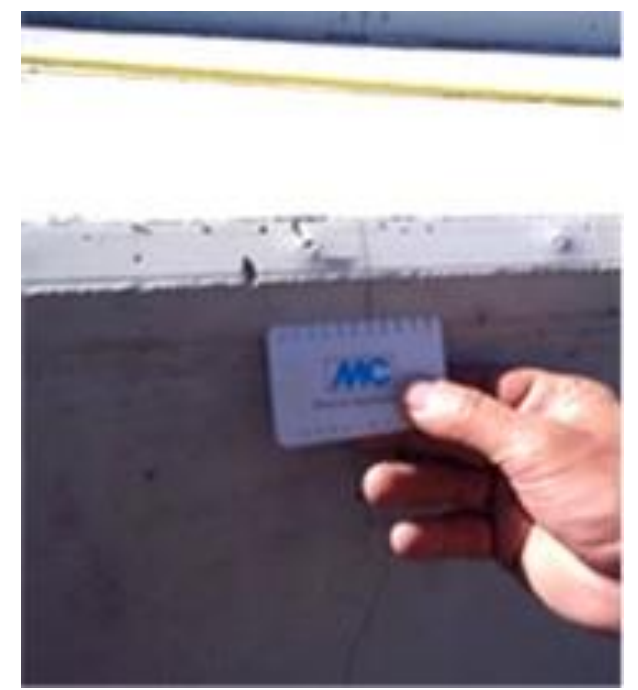

Figure 2. The illustration of crack width measurement using the crack width ruler

\section{RESEARCH RESULTS}

After the examination of concrete beams of the superstructure in quay No. 80A on the 13th of august, 2012, the vertical cracks were noticed every 0.9-5.8 m (Fig. 3).

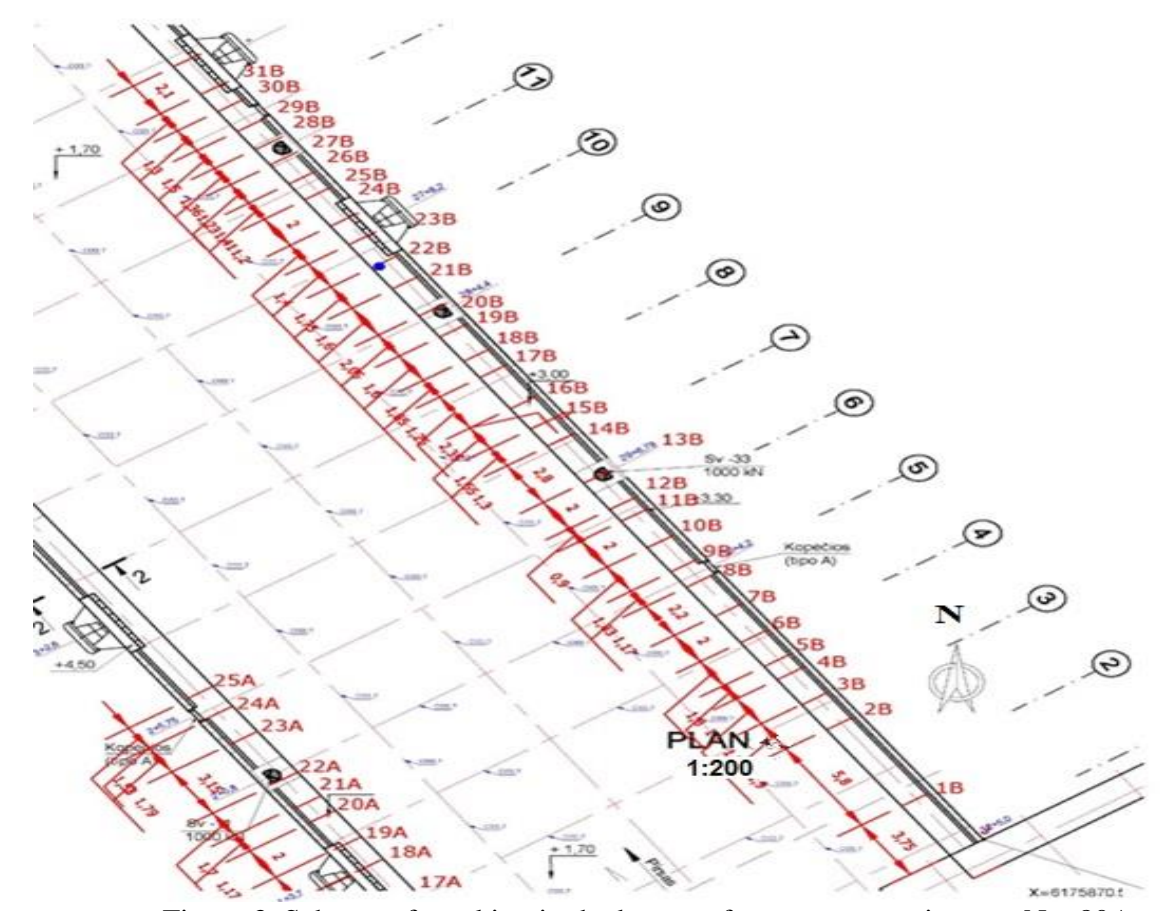

Figure 3. Scheme of cracking in the beams of superstructure in quay No. 80A 
The distance between cracks is greater in the part of beam (between the cracks No.1B and 2B) which was concreted on the 11th of April, 2012 in comparison with the rest of the beam which was concreted on the 11th of May, 2012.

During the examination the scale ruler was used and it was established that the widest cracks (up to $0.5 \mathrm{~mm}$ wide) are in the side beam of superstructure in quay No. 80A, these cracks are becoming wider from bottom to top. The concrete in this beam is the oldest, the works were performed on the 11th of April, 2012.

The crack width, distance between cracks measurement results using a crack width ruler and results of compressive strength test in reinforced concrete beams in the superstructure of quay No.80 performed by non-destructive test method are presented in Table 1.

Table 1. The crack width, distance between cracks measurement results and results of compressive strength test at reinforced concrete beams in the superstructure of quay No.80

\begin{tabular}{|c|c|c|c|c|c|c|c|}
\hline $\begin{array}{l}\text { Location } \\
\text { of crack }\end{array}$ & $\begin{array}{l}\text { Crack } \\
\text { width } \\
\text { on the } \\
\text { surface, } \\
\text { in mm }\end{array}$ & $\begin{array}{l}\text { Distanc } \\
\mathrm{e} \\
\text { between } \\
\text { cracks, } \\
\mathrm{cm}\end{array}$ & $\begin{array}{l}\text { Place of } \\
\text { measure } \\
\text { ment }\end{array}$ & $\begin{array}{l}\text { Average } \\
\text { compressive } \\
\text { strength } \\
f_{\text {cm.cub }} \quad \mathrm{MPa} \\
\left(\mathrm{N} / \mathrm{mm}^{2}\right)\end{array}$ & $\begin{array}{l}\text { Characteristic } \\
\text { compressive } \\
\text { strength } \\
f_{\text {ck.cub } \mathrm{MPa}}\end{array}$ & $\begin{array}{l}\text { Difference } \\
\text { from the project } \\
\text { characteristic } \\
\text { strength } \\
f_{\text {ck.cub }}=45 \mathrm{MPa}\end{array}$ & $\begin{array}{l}\text { Class } \\
\text { concrete } \\
\text { compressive } \\
\text { strength }\end{array}$ \\
\hline \multirow{2}{*}{ 1B } & \multirow{2}{*}{0.05} & \multirow{2}{*}{373} & side & 38.2 & 34.2 & -24.0 & $\mathrm{C} 25 / 30$ \\
\hline & & & top & 35.8 & 31.8 & -29.3 & $\mathrm{C} 25 / 30$ \\
\hline \multirow{2}{*}{$2 \mathrm{~B}$} & \multirow{2}{*}{0.25} & \multirow{2}{*}{140} & side & 36.5 & 32.5 & -27.8 & $\mathrm{C} 25 / 30$ \\
\hline & & & top & 46.8 & 42.8 & -4.9 & $\mathrm{C} 30 / 37$ \\
\hline \multirow{2}{*}{$6 \mathrm{~B}$} & \multirow{2}{*}{0.3} & \multirow{2}{*}{172} & side & 34.6 & 30.6 & -32.0 & $\mathrm{C} 25 / 30$ \\
\hline & & & top & 35.5 & 31.5 & -30.0 & $\mathrm{C} 25 / 30$ \\
\hline \multirow{2}{*}{$8 \mathrm{~B}$} & \multirow{2}{*}{0.1} & \multirow{2}{*}{220} & side & 33.8 & 29.8 & -33.8 & $\mathrm{C} 20 / 25$ \\
\hline & & & top & 33.3 & 29.3 & -34.9 & $\mathrm{C} 20 / 25$ \\
\hline \multirow{2}{*}{ 14B } & \multirow{2}{*}{0.1} & \multirow{2}{*}{281} & side & 34.5 & 30.5 & -32.2 & $\mathrm{C} 25 / 30$ \\
\hline & & & top & 36.4 & 32.4 & -28.0 & $\mathrm{C} 25 / 30$ \\
\hline \multirow{2}{*}{ 18B } & \multirow{2}{*}{0.1} & \multirow{2}{*}{127} & side & 35.8 & 31.8 & -29.3 & $\mathrm{C} 25 / 30$ \\
\hline & & & top & 35.0 & 31.0 & -31.1 & $\mathrm{C} 25 / 30$ \\
\hline \multirow{2}{*}{$22 \mathrm{~B}$} & \multirow{2}{*}{0.3} & \multirow{2}{*}{162} & side & 33.9 & 29.9 & -33.6 & $\mathrm{C} 25 / 30$ \\
\hline & & & top & 30.0 & 26.0 & -42.2 & $\mathrm{C} 20 / 25$ \\
\hline \multirow{2}{*}{$26 \mathrm{~B}$} & \multirow{2}{*}{0.05} & \multirow{2}{*}{123} & side & 33.7 & 29.7 & -34.0 & $\mathrm{C} 20 / 25$ \\
\hline & & & top & 31.0 & 27.0 & -40.0 & C20/25 \\
\hline \multirow{2}{*}{ 29B } & \multirow{2}{*}{0.1} & \multirow{2}{*}{140} & side & 35.9 & 31.9 & -29.1 & $\mathrm{C} 25 / 30$ \\
\hline & & & top & 32.8 & 28.8 & -36.0 & C20/25 \\
\hline \multicolumn{4}{|c|}{$\begin{array}{l}\mathrm{g} / \mathrm{b} \text { average values of strength of } \\
\text { superstructure structures }\end{array}$} & 35.2 & 30.0 & -33.3 & $\mathrm{C} 25 / 30$ \\
\hline
\end{tabular}

In accordance to the results of testing the concrete compressive strength of beams of reinforced superstructure in quay $80 \mathrm{~A}$, it was established the characteristic compressive strength $f_{\text {ck.cub }}$ of reinforced concrete beams in the superstructure is lower than the project characteristic strength $\left(f_{\text {ck.cub }}=45 \mathrm{MPa}\right)$ by 4.9 to $42.2 \%$.

\section{ANALYSIS OF RESEARCH RESULTS}

Causes of cracking. Based on the field investigation of cracks on the side beams of quay No.80A reinforced concrete superstructure it can be stated that cracks on the reinforced concrete beams were caused by concrete shrinkage, deformations, because beams were built on a solid reinforced concrete foundation. Such deformations are inevitable although their size depends on the following reasons (Gurskis, 2008, table 4.14):

- W/C ratio of concrete mixture, which in this research exceeds permissible values;

- Coarseness of selected aggregates $(\mathrm{D}=16 \mathrm{~mm}$ ) is too small, because the shrinkage depends directly on the size of aggregates and their volume in the concrete;

- Concrete stratification and possible lack of care for hardening concrete, because the density and the strength of surface layer of concrete is lower, therefore this layer is less resistant to cracking. Also, greater stratification of concrete in the research object could be affected by a spreadable concrete mixture (class of slump S3) which was used for the construction. This defect does not appear or appears in a weaker form in less plastic concrete mixtures (class of slump S1, S2), moreover their production requires less water and their characteristic is smaller shrinkage deformations.

Cracks width's limit values. The width of cracks in reinforced concrete side beams in the superstructure of quay No.80 is varying from 0.05 to $0.5 \mathrm{~mm}$. These cracks, which are $>0.20 \mathrm{~mm}$ wide, can be considered as damages, nevertheless a possible cause of cracking of these beams is the concrete shrinkage during the hardening and drying process of concrete, and not overload. These are non-constructional cracks and they do not reduce significantly the mechanical resistance of the structure and its stability which is one of the essential requirements for the structure. In any case, when cracks reach the width of $5 \mathrm{~mm}$, it should be considered that the structure is in an emergency state, because it would meet 
the characteristics of the emergency state indicated in the 1st appendix of Technical Construction Regulation STR 1.03.01:2016.

Having carried out the measurements of the distance between cracks and the width of cracks, the dependencies were established (fig. 4).

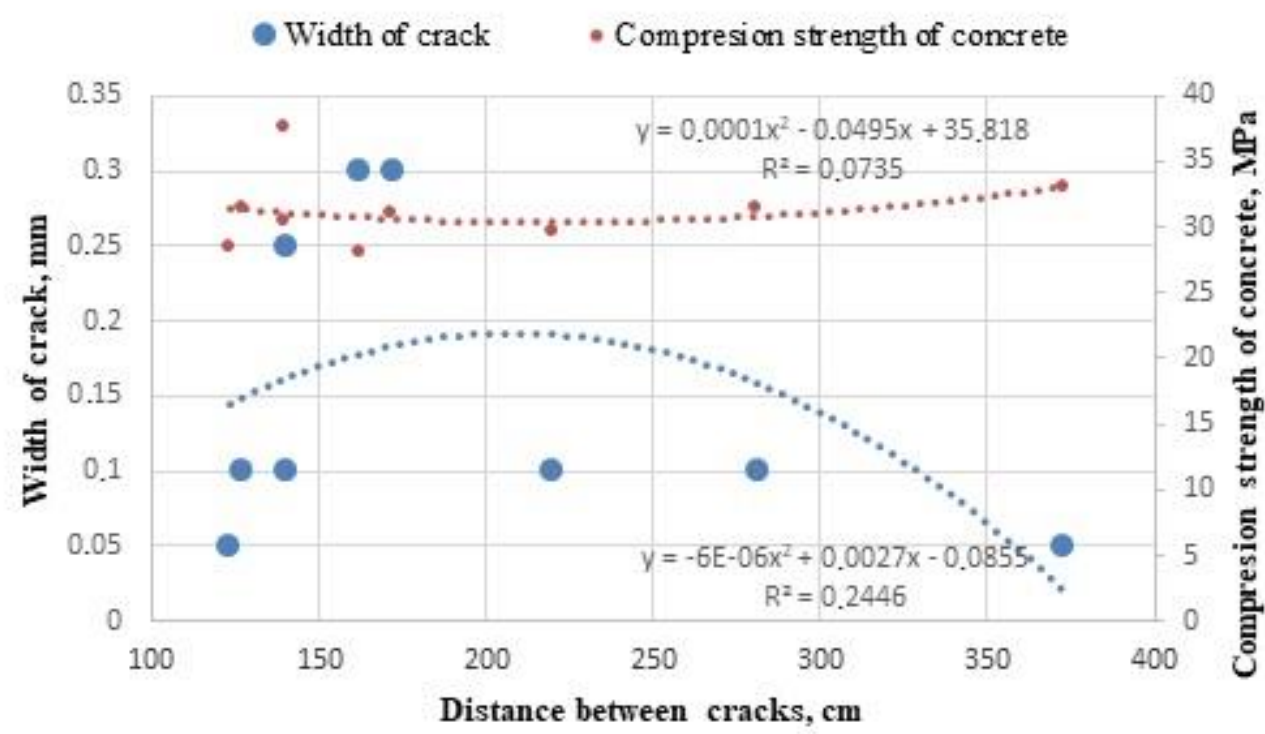

Figure 4. The dependencies of crack width and compressive strength of concrete on distance between the cracks of quay No.80A

It was established that the relationship between cracks' width and the distance between cracks was weak $\left(\mathrm{R}^{2}=0.2446\right)$ and values of concrete compressive strength has not any influence on cracks' width $\left(\mathrm{R}^{2}=0.0735\right)$.

\section{CONCLUSIONS}

Concrete shrinkage deformations caused cracks in quay $80 \mathrm{~A}$, because the temperature and shrinking joints were not installed. These joints are not necessary when quays beams and foundation are made almost simultaneously. To be exact, beams are made several days after the foundation is made.

Based on the results of the field investigation, cracks on the reinforced concrete superstructure side beams in the quay No. 80A can be defined as partly harmful, their width does not surpass the allowable limit values.

Having performed the analysis of the dependencies of cracks' width on the distance between cracks and the concrete compressive strength, it was established that the values of concrete compressive strength did not make any influence on cracks' width. It was also established that the relationship between cracks' width and the distance between cracks was weak.

\section{RECOMMENDATIONS}

In order to reduce the concrete shrinkage deformations in the research object, the constitution of concrete should be adjusted using aggregates of higher coarseness.

In order to control the compressive stresses during the process of concrete hardening and the tensile stresses during the changes of temperature, two solutions are possible:

1. During the calculations of the structure, additional internal forces, caused by temperature or humidity deformations in concrete and reinforced concrete are evaluated;

2. In order to make temperature and humidity deformations insignificant, deformation joints, which divide high and wide buildings or structures into different parts called temperature units, should be installed.

3. The change in time of width of temperature cracks should be observed by installing temporary recording or fixed mechanical strain gauges.

\section{REFERENCES}

1. Technical Construction Regulation STR 2.05.05:2005. Design of concrete and reinforced concrete structures [in Lithuanian]. Vilnius, Ministry of Environment of the Republic of Lithuania.

2. Technical Construction Regulation. STR 1.03.07:2017. Order of technical and maintenance supervision of buildings. Order of formation of new real estate cadaster objects (in Lithuanian). Vilnius, Ministry of Environment of the Republic of Lithuania.

3. Technical Construction Regulation. STR 2.02.06:2004. Hydraulic structures. The basic provisions [in Lithuanian]. Vilnius, Ministry of Environment of the Republic of Lithuania. 
4. Technical Construction Regulation. STR 1.03.01:2016. Inspection of Buildings. The collapse of the building [in Lithuanian]. Vilnius, Ministry of Environment of the Republic of Lithuania.

5. Technical Construction Regulation. STR 1.01.03:2017. Classification of structures [in Lithuanian]. Vilnius, Ministry of Environment of the Republic of Lithuania.

6. Compressive strength in structures and precast concrete components [in Lithuanian]. Vilnius, Lithuanian standards board.

7. Chen, J., Masoud, S., Xuehui, A., 2005. Experimental and numerical study of cracking behavior of openings in concrete dams. Computers and Structures, Vol. 83, No, 8-9, pp. 525-535.

8. European Standard EN 13791:2007 Assessment of in-situ compressive strength in structures and precast concrete components [in Lithuanian]. Vilnius, Lithuanian standards board.

9. European Standard EN 206:2013+A1:2017. Concrete - Specification, performance, production and conformity [in Lithuanian]. Vilnius, Lithuanian standards board.

10. European Standard EN 12504-2:2012. Testing concrete in structures. Part 2: Non-destructive testing. Determination of rebound number [in Lithuanian]. Vilnius, Lithuanian standards board.

11. Expertise of cracks appeared in concrete side beams in the object "The installation of the infrastructure of passenger and cargo terminal". Chairmen: V. Damulevicius, head of part of project: JSC "GETELIT", head of special inspection: A. Mecius, project operators: R. Sadzevicius, V. Gurskis, A. Vaitiekunas. Client: Klaipeda State Seaport Authority. 2012.

12. Gurskis V., 2008. Building materials [in Lithuanian]. Kaunas, Ardiva.

13. Jokubaitis V., Sauciuvenas G., 2012. Evaluation of technical state of building structures: study book [in Lithuanian]. Vilnius, Technika.

14. Kheder, G. F., 1997. A New Look at the Control of Volume Change Cracking of Base Restrained Concrete Walls. ACI Structural Journal, Vol. 94, Iss. 3, pp. 262-271.

15. Kheder, G.F., Rawi, R.S.A. and Dhahi, J.K.A., 1994. "A Study of the Behavior of Volume Change Cracking in Base-Restrained Concrete Walls". Materials and Structures, Vol. 27, pp. 383-392.https://doi.org/10.1007/BF02473441

16. Rawi, R. S. A. and Kheder, G. F., 1990. Control of Cracking Due to Volume Change in Base-Restrained Concrete Members. ACI Structural Journal, Vol .87, Iss. 4, pp.397-405.

17. Recommendations of the Committee for waterfront Structures Harbours and Waterways EAU 2012. 